\title{
STATUS OF KURDS IN IRAQ IN TERMS OF CONSTITUTIONAL LAW AND NATIONAL IDENTITY
}

\begin{abstract}
Recently, with regard to the Middle East, Slovak and foreign media have focused on the situation in Syria. However, equally important is political development in Iraqi Kurdistan in which plebiscite in September 2017 showed that almost 90 percent of Kurds request independent Iraqi Kurdistan. According to many indicators and claims by geopolitical analysts, the conflict between Baghdad central government and Iraqi Kurds is growing and will escalate, what will lead to an increase of Iraqi Kurdish struggles to establish a state independent of Iraq. Our study, however, wants to point out to the fact that there are also opposing trends indicating of continual centralization of Iraq and the Kurdistan integration into the Iraqi state. Based on this analysis we criticize the thesis of American geopolitical theorists such as R. Peters the emergence of an independent Kurdistan.
\end{abstract}

KEYWORD: kurds, Kurdistan, independence, self-determination, identity.

\section{INTRODUCTION}

This study, is aimed to point out to the fact that there are also opposing trends indicating of continual centralization of Iraq and the Kurdistan integration into the Iraqi state. Based on this analysis we criticize the thesis of American geopolitical theorists such as R. Peters the emergence of an independent Kurdistan. It is very questionable whether Kurdistan will after plebiscite in September 2017 achieve independence or will remain integrated within the Iraqi state. In this work, we want to point out that the assertions of many political commentators on the gradual efforts of Iraqi Kurdistan will 
lead to independence are only one possible hypothesis of development. There are also indications that there is a strong centralization of Iraq. Therefore we provide an analysis of the Iraqi constitution adopted in 2005 in terms of the Kurds. Based on this analysis, we want to demonstrate that the constitution will not lead to the federalization of Iraq, as many political analysts say. On the contrary, the constitution is an expression of the efforts of Iraqi Arab political elites to centralize political power in Baghdad.

We will also deal with the Kurds in terms of their identity. We have questioned the impact of the centralization of power by the Arab elites in Baghdad on the position of the Kurdish ethnic group. Will the Kurds consider centralization of power as a threat to their identity? Will the Kurds, as a result of the centralization of compulsion, look for the possibility of creating a new state? In answering these questions, we used the model of social constructivism by $\mathrm{M}$. Barnett. Based on this, we have set a hypothetical scenario on how to develop the political situation in Iraqi Kurdistan and what geopolitical consequences it will bring. Will an independent entity with its own foreign policy arise? Many geopolitical analysts in the West often predict the breakup of Iraq and the emergence of an independent Kurdistan in response to centralization. Among them is the US Geopolitical Analyst and former US Department of Defence Staff Colonel R. Peters. Therefore, in the final part, we want to give our attitude to his arguments to what extent they are justified.

\section{HistoricAl AND CONSTITUTIONAL DEVELOPMENT OF IRAQI KURDS}

The Kurds are considered to be the original inhabitants of areas where they live today. They are the product of the evolution of several tribes such as Guts, Kurts, Mans, Meds, Khalds and other Indo-European tribal communities that immigrated to Zagros Mountains around 4000 BC. The name Kurdistan means in the translation of the "Kurdish Land", and first appeared in the 12th century when the Turk of Saudi Arabia established an equivalent province that corresponded territorially with the area inhabited by the Kurds of Iran. At present, the mountainous areas of Iran, Iraq, Syria, Turkey, particularly Armenia and Azerbaijan are considered Kurdish. However, exact 
determination of borders and territory is impossible, since Kurdistan is not a sovereign state. With regard to the population, the determination of this indicator is extremely difficult, since Kurds are generally considered to be the largest ethnic group without their own state in the world (Yildiz, Blaz, 2003). In the past Kurds enjoyed a relatively high degree of autonomy. The powers that controlled these areas were used by the Kurdish services to maintain peace in their border territories (Yildiz, Blaz). The first option for the Kurds to have their own state came after World War I and disintegration of the Ottoman Empire. However, Kurdish self-determination was limited by rivalry between various Kurdish groups. The clear moment for the Kurds was the 14-point renown of US President W. Wilson, which resulted in the formation of the first Kurdish diplomatic delegation focused on relations with the US, with the emphasis on their performance at the Paris Peace Conference. One of the points mentioned was that the non-Ottoman nationality of the former Ottoman Empire should have guaranteed "no undisturbed possibility for autonomous development" (LaFeber, 1994, p. 110). Although, in our point of view, this provision was very vague, in particular the formulation of so-called autonomous development, Kurdish nationalists hoped to establish a separate and sovereign Kurdistan. An important international document governing the possibility of the emergence of an independent Kurdish state was the Sèvres Treaty of 1920, which, in Articles 62-64, governed, in particular, the conditions for the formation of that State. However, the failure to ratify this document prevented the act of unification, and in addition the subsequent Treaty of Lausanne (1923) did not at all change the status of the Kurdish state itself and was granted minority status in the countries it inhabits. This led to the possibility of unification of the Kurds, with the emergence of the state of Iraq in 1931 completely stopping this process. However, the development of the Kurdish issue over the next three decades in Iraq was not as bad as the level of their rights was the highest of all Kurdish states. Let us mention, for example, the ability to teach in Kurdish primary schools (since 1931), recognition of Kurdish nationality (1958) and limited autonomy from 1974 (Katzman, 2009). Subsequently, there were various persecutions and reprisals in the Kurds after the rise of S. Hussein's power, and the Kurdish question remained unresolved. This stage of Iraqi history is characterized by 
considerable instability and minimal effort to democratize society and the welfare of citizens (Manafy, 2007).

After the US invasion of Iraq, Kurds joined the Iraqi opposition faction, operating as a resistance political group. After the war, the situation in region was relatively calm, except for various destabilization efforts by Iran and Turkey, such as the bombing of border areas, because they were afraid of the growing political force of the Iraqi Kurdistan. The creation of the Kurdish regional government and the adoption of the new Iraqi Constitution of 2005 were very important from a national and international point of view. Kurdish political elites presented it as a historical milestone or success, especially in relation to the long-standing oppression of the Kurds. This constitution was adopted by 80 percent of voters in a referendum overseen by the UN. Regarding the state - legal point of view, the fundamental basis of this document is the establishment of a federation with a relatively high level of decentralization and an attempt to progressively build democracy in that state. Constituents of the Iraqi constitution could also be called "victims of Saddam's regime," as they are Iraqi Shiites and leading representatives of the Kurdish minority. They came to the consensus that recentralized Iraq would be a threat to existing national minorities, religious communities and citizens (Katzman, 2009). The Iraqi Constitution incorporated provisions that recognize the Kurdish autonomy in Iraq, and there is also a definition of powers between the center and individual regions, which we can historically regard as a step forward. But it must be brought to light by the many negatives and contradictions that this constitution brings. The first and fundamental thing is that the constitution itself does not recognize two peoples as Arab and Kurdish as one of the fundamental attributes of its state. Kurdish is mentioned in Article 4, Kurdistan, or the Kurdish region in Articles 5, 114 and 137, but no constitutional provision in the Iraqi constitution is the term Kurdish nation. On the other hand, in our opinion, it is quite unusual that in the text of the Constitution, the Turkmens, Assyrians, and Chaldeans. Another, in our opinion, inconceivable concept within the Iraqi constitution is the very form of the state, the territorial and administrative configuration, which ultimately negatively influences the status of the Kurds in Iraq. The Constitution of Iraq states that the territorial - administrative configuration 
of Iraq is constituted by the capital, regions and the Mufahazat region with the possibility of creating new administrative - administrative units. Is this a federation or union? In our opinion, this is a very unfortunate concept of administrative federalism and not an arrangement based on geographic, ethnic or historical regional differences. This system is unclear and the powers of self-governing units and regional authorities are very limited and cannot be compared to those at central level.

The regional constitutions, if they can be called upon, and other regulations with lower legal force must be in full compliance with the central constitution, and therefore the task of the Kurdish Legislative Assembly is only to interpret and implement the laws adopted in Baghdad and, in the event of non-compliance rules Federal court, which is exclusively of exclusively judges of the Arab nationality. (Katzman, 2009) This only confirms the premise that Iraq is not a federation in the true meaning, and that also the possibility for the Kurds to actively participate in governance in matters of a nationwide nature is limited. In Iraq, dominated by a ruling majority state, the Constitution very clearly enshrined the Islamic identity of the State of Iraq through many provisions (Katzman, 2009). The second article of the Constitution reads as follows: "No law can be adopted contrary to the Islamic legal system, no law can be adopted contrary to democratic principles, and no law can contravene fundamental rights and freedoms regulated in the constitution." Not just quoted but many others the articles of the Constitution are very contradictory. At first glance, a critical attitude is needed to compare the conflict of Islamic law with democratic principles, which clearly shows that the application of certain terms, concepts and institutes itself is incomprehensible, which makes it a source of law that makes it difficult to accept comprehensive legislation. There are no articles on Kurdish dearabiishing due to the repressive policy of the S. Hussein regime, which has been linked to genocide, and the Kirkuk area, which is not part of the Kurdish regional government area, is very controversial, not to mention another 40 percent of the former Kurdish Territories which were excluded from the Kurdish administration during the reign of S. Hussein. Ultimately, the rights of national minorities are generally subject to wide cultural and legal restrictions. From these facts, we have several conclusions. The Iraqi 
constitution is a manifestation of the ambiguity, vagueness and effort of the Arab political elites in Iraq to concentrate power, alibistically referring to the quasi-federal form of the state. It is a great failure of the states that have committed themselves to the adoption of this Constitution that many Kurdish rights that have been declared in the past have remained on the periphery, and their right to self-determination is not, in our view, realistic. The Constitution does not take into account the geographical, cultural and ethnic specificities of the Kurdish ethnic group. The ability of regional governments to participate in state governance is to a large extent limited, as documented by the above facts concerning the enumeration of powers between the center and the self-governing units. (Terem, Rosputinsky, 2018) That is why we think that a country where there is no democratic tradition is not and will not yet be able to guarantee the required level of political participation of the regions and the possibility of self-determination of the Iraqi Kurdistan.

\section{NATIONAL IDENTITY OF THE KURDS AND GEOPOLITICAL IMPACT ON THE REGION}

Based on the above-mentioned analysis of the Iraqi constitution, we can generally state that the Iraqi constitution is insufficient to guarantee the autonomy of the Kurdish authorities and the particular position of the Kurdish ethnic group within Iraq. On the contrary, the constitution demonstrates the efforts of Iraqi Arab political elites to centralize power. This is precisely why, based on social constructivism, we have decided to establish a hypothesis about the influence of the centralization of power by Arab elites on political developments in Iraqi Kurdistan in the present and near future after the plebiscite in September 2017. Firstly we would like to briefly describe the theoretical and methodological framework in which we set the hypothesis. One of the key concepts of social constructivists, from which we will also be based, is identity. Identity is a way of perceiving and characterizing people, and therefore peoples or ethnicities, in relation to the surrounding material world. This identity rests on the common historical, cultural, political and social aspects shared by individuals within a particular community, such as ethnicity, nation, state (Nia, 2011). In our case, we will be particularly interested in the historical aspect, as the collective history 
of the Iraqi Kurds is characterized by the absence of its own independent state. Another important aspect of the Kurd's common historical memory is oppression by the regime. In this case, our opinion is that the policy of the overthrown Iraqi President S. Hussein, which suppressed the development of the identity of the Kurds, encouraged the Arabization of the Kurdish areas, and even violently suppressed any Kurdish resistance to the central government. In the light of the theory of constructivist M. Barnett (Telhami et al., 2002) we can say that these powerful historical moments - the denial of the right to their own state and oppression by the regime - became historical narratives, a story that defined a common memory, identity of Iraqi Kurds. As mentioned by M. Barnett (Telhami et al., 2002), this identity based on shared memory provides new frameworks - explanation of phenomena and events. In our case, it will be important to see what impact it currently has and in the near future it will have the following event: the adoption of the Iraqi constitution in 2005, plebiscite in September 2017 and possible future attempts to centralize power by the Arab elites. The question, therefore, is whether the Kurdish community will interpret this event as an opportunity or a threat as a result of its historical memory. Based on this model of M. Barnett, we have determined the following hypothetical scenario, which will affect the event, the adoption of the Iraqi constitution and efforts to centralize it, the political developments in Iraqi Kurdistan in the present and the near future.

\section{HYPOTHESIS BASED ON THE M. BARNETT'S THEORY}

Denying the right to state and oppression by the regime is a powerful historical narrative. These narratives provide a framework, interpretation, for the event - in our case; it is the adoption of the constitution in 2005 and efforts to centralize power by the Arab elite in Baghdad. In the context of these narratives, the Kurds will perceive the adoption of the Constitution as negative, as the concentration of power of the Arab elite refers to the historical experience of oppression by government regimes and the lack of emphasis on the individuality of the Kurdish ethnicity is a reference to the denial of the right to self-determination against Kurds in the past. It is therefore clear that, in view of their historical experience, the Kurds will regard integration 
into the Iraqi state based on this institution as a threat to their identity. In this regard, there will be an increased effort by the Kurds to strengthen their own national identity and efforts to gain independence from the Baghdad government. The geopolitical impact on the region should be the gradual formation of an independent entity with its own foreign policy, what was proved by the successful regional plebiscite in September 2017, but the formation of independent state is more than questionable.

Regarding the probability hypothesis verification based on the Barnett model, we would first point out some numerical statistics on the election of the President of the Kurdish Region in 2009 (Electoral Commission ..., 2009). In these presidential elections, M. Barzani won a vote of 69.6 per cent. M. Barzani is a politician who did not rule out the possibility of a future Kurdistan-independent Iraq (Bengio, 2012). Another 25 percent of voters passed the vote of K. Mirawdly, who is a member of the Kurdistan Referendum Movement (2005) International Kurdistan Referendum Movement. Based on these results, we can say that they support our hypothesis based on Barnett's model, a significant part of the Iraqi Kurdish community after 2005 supports the idea of independence. On the other hand, it must be borne in mind that elections and plebiscite in 2017 itself cannot be a sufficient indicator of whether Kurds are beginning to be defined as a separate nation and form an independent state. First of all, it is questionable how many voters voted by priority according to the criterion whether the candidate supports Kurdish independence. Secondly, it is necessary to realize that Kurds are not a homogeneous ethnic. Kurdish identity is also greatly fragmented among the different tribes and clans. For example, the Jazid tribe. 300,000 members of the Jazid tribe inhabited the territory of Iraq, with 95 per cent of them living in the Iraqi Kurdish-controlled territories (Iraq’s Yezidis, 2005). Leading Kurdish political leaders consider them Kurdish, although Jazidi is considered to be a separate entity. On the one hand, it is true that many of these candidates are accustomed to being on lists of Kurdish nationalist parties. For example, in January 2009, eight of the 12 candidates won the election in the provincial council in Nineveh. These candidates, however, do not consider it a way of identifying themselves with the Kurdish ethnicity, but rather the possibility of gaining power over the influential parties and representing the interests of 
the Jazid tribe (Robertson et al., 2009). In addition, Jazidi also has his deputies in the Iraqi Parliament in Baghdad (Bozani, 2007).

Jazid's attempts to be represented in the Iraqi parliament suggest that individual Kurdish tribes do not perceive central power in Baghdad as a threat to their identity. On the contrary, they seek to promote their own interests through membership in central bodies. As we can see in the example of the ethnicity of Jazid, it is difficult to speak unequivocally about the attempt to create a united Kurdish nation and efforts to gain independence from Baghdad. Therefore, we can say that it is very difficult to establish hypotheses purely on the basis of constructivist models, in our case, the M. Barnett model. As can be seen, historical narratives of central government oppression or denial of the right to self-determination do not yet lead to the Kurdish tribes trying to enhance their national identity in a distinctive way and seek independence from the central Baghdad government. Finally, we may notice the case of Iraqi President Talabani himself, who is a member of the Taliban northern Kurdish tribe. His tribe's officers control other important positions in the Iraqi central government, such as the Iraqi Ministry of Water Resources and the post of Iraqi Ambassador to China (Rubin, 2008). As you can see, Iraqi Kurds do not have to explicitly perceive the centralization of power by the Arab elites in Baghdad as a threat. On the contrary, many Kurdish tribes can see it as an opportunity to strengthen their own status, so they place their members in Iraqi government bodies. Regarding the geopolitical impact on the region, we cannot unambiguously argue that despite above mentioned reasoning, a new independent entity with its own foreign policy will be created.

As mentioned above, Kurds are a non-uniform community divided into different tribes. This is also reflected in their relations with foreign countries. An example is the case of Sunni Iraqi Vice President T. al-Hashimi. This vice-president was accused of being at the head of preparing assassinations against Iraqi Shiite political leaders to bring about sectarian violence in Iraq. In December 2011, the Iraqi Judicial Council issued an arrest warrant to T. Al-Hashimi. T. al-Hashimi subsequently escaped to Iraqi Kurdistan in order to avoid the lawsuit in Baghdad. He then fled to Turkey. The Turkish government refused to issue T. al-Hashemi to the Iraqi authorities. For a long time, Turkey has been criticizing the Iraqi government led by Shiite Prime 
Minister N. al-Malikim for his efforts to concentrate his power, and this process against T. al-Hashimi is to be used to remove the opponents (Iraqi fugitive ..., 2012). On the one hand, the Kurdish regional government, led by President M. Barzani, backed T. al-Hashemi, refused to give the Iraqi Vice President and allow his exile to Turkey. In this context, it must be added that President Barzani is a member of the influential Kurdish tribe Barzani (Barzani Tribe's ..., 2011). On the other hand, the leaders of the tribe, including Iraqi Kurdish President J. Talabani, supported the Iraqi central government and appealed to the Turkish and Kurdish regional governments to hand T. al-Hashemi to the Iraqi authorities (Fugitive Iraqi VP ..., 2012).

We can therefore conclude that Barnett's model does not sufficiently clarify the reality, even with regard to Kurdish foreign relations, not just the internal political situation. Under certain circumstances, we can talk about creating a new independent entity. As can be seen, the Kurdish community does not unanimously see centralization of power by the Baghdad government as a threat. Instead of using the controversy within the Iraqi government to strengthen autonomy, Kurdish political leaders are actively involved in Baghdad's political process. This intra-political crisis uses individual tribes to strengthen their own position against other tribal clusters, but within the Iraqi state. In the field of international relations, as we have seen on the example of the Iraqi Vice President, this was reflected in the mixed attitude of the Kurdish elites towards Turkish politics. From this point of view, we cannot talk about the creation of a new single state unit, even after successful plebiscite. We may generally state that it is very difficult to predict the script purely on the basis of constructivist models.

\section{Geopolitical map of IraQ Designed By R. Peters}

Based on the aforementioned analysis, we believe that the consideration of several foreign geopolitical theorists advocating the emergence of an independent Iraqi Kurdistan is evidence that they ignore the tribal contradictions within Kurdish ethnicity. An example is the proposal of a US geopolitical analyst and former Colonel R. Peters Minister of Defence. According to M. Barnett, R. Peters points to the fact that the US and its coalition partners made a mistake when, after the invasion in 2003, began 
to support Kurdish integration within the Iraqi state. Instead, they should correct historical injustice and allow the Kurds to create their own state that most Kurdish communities want (Peters, 2006). It is clear from these statements by Mr. Peters that he ignores the essential facts, namely the tribal contradictions. He points to the Kurdish community as a whole, wishing independence as a remedy for denial of the right to its own state in the past. On the other hand, it no longer reports that many Kurdish tribes have used the central government to strengthen their influence. An example may be the policy of former Iraqi President S. Hussein, who used the mainstream controversy within the Kurdish community.

The Kurdish tribes of Sorchy, Mezouri, Doski, Herki, and Zibari volunteered the mercenaries of S. Hussein to fight against the competitive Kurdish tribal clusters. During the Iraqi-Iran war in the 1980s, up to 150,000 members of these Kurdish tribes were in the Iraqi army (Taylor, 2005). Another argument by R. Peters is that the emergence of an independent Iraqi Kurdistan would have a positive geopolitical impact on the US and their Western allies. According to R. Peters, Iraqi Kurdistan would be a proWestern and pro-democratic state in the region (Peters, 2006). On the one hand, it is, of course, true that such a government could be of benefit to the US and its allies from a geopolitical point of view, but on the other the result of the plebiscite from September 2017 wasn't welcomed by the EU, Russia and Turkey and other regional powers.

Progressive Kurdistan would be a barrier to the impact of the anti-Western Iranian regime in the region. Based on the above-mentioned analysis, it is clear that the common elements of identity, as Mr Barnett argues, do not necessarily have to lead to the emergence of a new entity. The M. Barnett model inadequately explains why collective differences often prevail over shared identities. In our case, it is clear that tribal contradictions often prevail (in possible future formation of the new entity) over common elements such as collective historical memory. For this reason, despite the fact that Iraqi Kurds have been oppressed in history by the central government, a huge part of them do not consider centralization of power as a threat. On the contrary, cooperation with central government authorities often leads to strengthening the power of the tribe over other tribal clusters. 
On the other hand, the question is whether the Kurds are actually a proWestern community. Examples are Iraqi Kurdish relations with the Iranian theocratic regime. For example, in 2007, members of the US Armed Forces arrested six members of the Iranian intelligence service during the Kurdish armed forces in Erbil and Sulaymaniyah. Interestingly, the office of Kurdish President M. Barzani in the statement did not respond to the presence of Iranian intelligence services on his territory but condemned the US Army's actions as they had not previously informed the Kurdish government about the interference (Rubin, 2008). Despite the international sanctions against Iraq, Iraq continues with the Iranian regime in trade relations, with $70 \%$ of trade with Iran being implemented through the Kurdish regional government (Rubin, 2012). It is clear that leading Kurdish political leaders are not against developing cooperation with anti-Western regimes, as in Iran. From this point of view, American geopolitical claims such as R. Peters on the proKurdish community are largely unsubstantiated. Rather, in this case, there are significant tribal contradictions, as in the case of the above-mentioned Vice President T. al-Hashemi. He is a well-known by his anti-Iranian attitude, criticizing Iran for incitement of sectarian violence in Iraq. If the Kurds were genuinely a pro-democracy and pro-Western community, they unambiguously condemned the policy of Iraqi Prime Minister N. al-Maliki, who is trying to exploit these processes against the political opposition to power. They also stood on the side of Vice President T. al-Hashemi. On the contrary, part of the communities supported Turkish politics and partly supported the policy of the central Iraqi government, which cooperates with Iran.

\section{Conclusion}

Finally, we can state that our established hypothesis based on the M. Barnett model does not match much with reality. The reason is that, according to several indicators, the factors common to the entire Kurdish ethnic group do not coincide with oppression and denial of the right to selfdetermination in the past. Instead, the division of the Kurdish community into individual tribal groups prevails. Many of these tribal clusters do not see centralization of power by the Baghdad government as a threat. On the contrary, good relations with the central power can lead to the strengthening 
of one tribe at the expense of other clusters. From this point of view, we can not in any way talk about the emergence of a collective Kurdish identity, which will lead to an independent state on the geopolitical map of the Middle East region. Moreover, in their relations with foreign countries, these tribal contradictions have repeatedly manifested itself in the inconsistent approach of Kurdish political figures, for example, in the case of Turkey, which refuses to give the Iraqi vice-president to Iraqi authorities. From this point of view, we believe that several Western geopolitical theorists like R. Peters are mistaken in advocating the emergence of an independent Iraqi Kurdistan. Because of the considerable fragmentation, it is impossible to speak of a uniform identity. Moreover, talking about the geopolitical contribution of an independent pro-Iraqi Kurdistan is also very controversial. Several cases show that Iraqi Kurdish political leaders are also able to work with anti-Western political regimes. The relations of Iraqi Kurdish politicians with foreign countries are determined primarily by tribal disagreements and not by the pro-Western orientation of the Kurdish community, as R. Peters claims.

\section{References:}

Bengio, O. 2012. Will Barzani declare independence? [online] In Jerusalem Post. 2012. [accessed: 13. 10. 2017] Available at: http://www.jpost.com

Bozani, K. 2007. The Yazidi's past and present. [online] In Niquash. 2007. [accessed: 20. 10. 2017]. Available at: http://www.niqash.org

Electoral Commission announces final results of Kurdistan Region elections. 2009. [online] In Kurdish Regional Government. [accessed: 7. 10. 2017] Available at: http://www.krg.org

Fugitive Iraqi VP should be handed over, president's tribe said. 2012. [online] In PressTV. [accessed: 27. 10. 2017] Available at: http://www.presstv.ir

Iran is Behind Sectarian Strife. 2012. [online] In Euronews. [accessed: 6. 10. 2017] Available at: http://www.euronews.com

Iraqi Constitution. 2005. [online] In uniraq.org. [accessed: 16. 10. 2017] Available at: http://www.uniraq.org

Iraqi Fugitive Sunni VP Hashemi Death Squad Trial Delayed. 2012. [online] In Kurd Net. [accessed: 9. 10. 2017] Available at: http://www.ekurd.net

Iraq's Yezidis. 2005. [online] In Aina.org. 2005. [accessed: 9. 10. 2017]. Available at: http://www.aina.org 
Kurdistan Referendum Movement - International Committee. 2005. [online] In Kurdmedia. 2005. [accessed: 23. 6. 2017] Available at: http://www.kurdmedia.com

Mirwaisi, H. 2011. Barzani tribe's occupations of Erbil, Iraqi Kurdistan, are coming to an End Soon. [online] In Kurd Net. 2011. [accessed: 11. 10. 2017] Available at: http://www.ekurd.net

Nia, M. M. 2011. A Holistic Constructivist Approach to Iran's Foreign Policy. In International Journal of Business and Social Science. New York : Centre for Promoting Ideas. Vol. 2, No. 4, ISSN 2219-1933. p. 279 - 294.

Peters, R. 2006. Blood Borders. [online] In Armed Forces Journal. 2006. [accessed: 18. 10. 2017] Available at: http://www.armedforcesjournal.com

Robertson, C., Farrell, S. 2009. Ancient Sect Navigates Iraq's New Voting Process. [online] In: New York Times. 2009. [accessed: 28. 10. 2017] Available at: http:// www.nytimes.com

Rubin, M. 2008. Is Iraqi Kurdistan Good Ally? [online] In Middle East Forum. 2008. [accessed: 20. 10. 2017] Available at: http://www.meforum.org

Rubin, M. 2012. Is Iraqi Kurdistan Iran's Troyan Horse? In Commentary Magazine. 2012. [accessed: 2. 11. 2017] Available at: http://www.commentarymagazine.com

Taylor, R. L. 2005. Tribal Alliances: Ways, Means and Ends to Successful Strategy. [online] In Strategic Studies Institute. 2005. [accessed: 21. 10. 2017] Available at: http://www.au.af.mil

Terem, P., Rosputinský, 2018. Legal and political aspects of the Kosovo's unilateral declaration of independence. In: Kosovo: Sui generis or precedent in international relations. Belgrade: Institute of International Politics and Economics. 2018. ISBN 978-86-7067-249-9

Telhami S., Barnett, M. 2002. Identity and Foreign Policy in the Middle East. London: Cornell University Press, 2002. 207 p. ISBN 978-0-8014-3940-7.

\section{Endnotes}

${ }^{1}$ JUDr. Matúš Štulajter, PhD is an assistant specialist at the Department of international law and diplomacy of the Faculty of political sciences and international relations. He mainly focuses on various areas of international and european union law. 